\title{
Research evaluation: implementing a clear framework
}

\author{
Avaliação da pesquisa: implementando um claro quadro de referência
}

Isabel Pinho*

\section{Abstract}

Research Evaluation is being done with many different evaluation frameworks and uses many tools for gathering appropriate data, but no single approach works in all contexts and for all purposes. In this article we reflect on designing a research Evaluation with a focus on the Planning task. Through answering to thirteen questions we can follow a Research Evaluation Chain Decision Process in order to choose adequate tools and metrics to achieve the purpose of the Evaluation.

Keywords: Research evaluation. Framework. Tools. Metrics. Research evaluation system.

\section{Resumo}

A avaliação da pesquisa está sendo feita com variados quadros de referência de avaliação e usa muitas ferramentas para coletar os dados apropriados, mas nenhuma abordagem única funciona em todos os contextos e para todos os objectivos. Neste artigo, refletimos sobre a criação de uma avaliação de pesquisa com foco na tarefa de planeamento. Ao responder a treze perguntas, podemos seguir um Processo da Cadeia de Decisão na Avaliação de Pesquisa, que visa escolher as ferramentas e as métricas adequadas para alcançar o propósito da avaliação.

Palavras-chave: Avaliação de pesquisa. Quadro de referência. Ferramentas. Métricas. Sistema de avaliação de pesquisa.

Recebido em 10/05/2018 - Aprovado em 05/09/2018

http://dx.doi.org/10.5335/rep.v26i1.8404

PhD in Management from the University of Aveiro. Post Doc in Higher Education, supervised by Professor Denise Leite, in the Graduate Program in Education, Faculty of Education, Federal Universidade do Rio Grande do Sul (UFRGS). Researcher at the Research Unit on Governance, Competitiveness and Public Policy (Govcopp) in Universidade de Aveiro, Portugal and Grupo de Pesquisa Inovação e Avaliação (InovAval) - UFRGS, in Brazil. 


\section{Introduction}

Research Evaluation can be defined as the systematic acquisition and assessment of information to communicate explicitly the value and merit of research. This can be performed at various levels (macro, meso and micro). At macro level we can evaluate a national research policy (GLÄNZEL; LETA; THIJS, 2006; PACKER; MENEGHINI, 2006; BERTOLIN; LEITE, 2008; FELIX, GODOY BERTOLIN; MOROSINI POLIDORI, 2017), a supra national research program (TOIVANEN; PONOMARIOV, 2011) or a global knowledge network (LEYDESDORFF; PERSSON, 2010; SUN; MANSON, 2011); at meso level it is possible to perform research evaluation at institutional (LEITE, 2005; QUINTELLA et al., 2009), or organizational levels (BOARDMAN; CORLEY, 2008; QUINTELLA et al., 2014) such as evaluations with a university or research center scope; at micro level the focus can be the individual researcher, a group or ego-network (BOZEMAN; CORLEY, 2004; LEITE et al., 2014).

\section{Designing Research Evaluation}

What is the best Research Evaluation Model? This question is the starting point when we need to implement a Research Evaluation System and we need to design it (HANSEN, 2005). Some Declarations and Manifesto (Figure 1) give the main recommendations and guiding principles, such as:
a) The Declaration of Helsinki;
b) Declaration of Havana Towards Equitable Access to Health Information;
c) Budapest Open Access Initiative (BOAI);
d) The Bethesda Statement on Open Access Publishing;
e) The Declaration of Berlin on Open Access to Knowledge in the Sciences and Humanities;
f) Kronberg Declaration on the Future of Knowledge Acquisition and Sharing;
g) The Declaration of Brisbane;
h) Panton Principles for Open Data;
i) The Cost of Knowledge Manifesto;
j) The San Francisco Declaration on Research Assessment (DORA);
1) The Hague Declaration; and
m) The Leiden Manifesto for research metrics.
In Annex 1 we provide the websites links. 
Figure 1 - Manifestos and declarations timeline

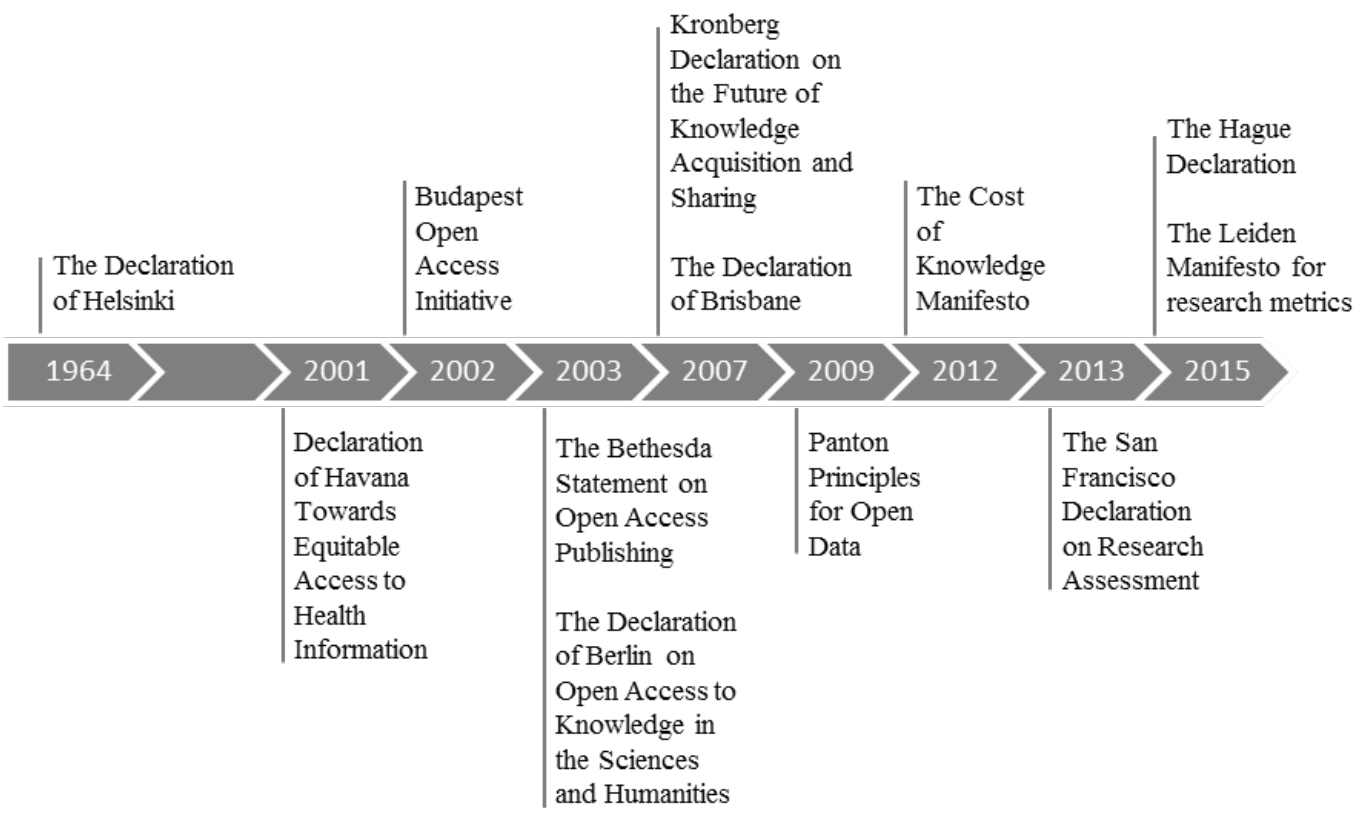

Source: the author.

We highlight the Leiden Manifesto that appeals to responsible and clear use of indicators by providing a distillation of best practice in metrics-based research assessment inform of ten principles, in order to avoid a pervasive misapplication of indicators to the evaluation of scientific performance (see Table 1).

Taking into account these principles it is possible to build research evaluation systems to support decision-making about science "combining robust statistics with sensitivity to the aim and nature of the research that is evaluated" (HICKS et al., 2015, p. 431). Among these principles some are fundamentals such as the need of data collection and analytical processes open, transparent and simple.

We must reinforce that the entire process of research evaluation must be participatory, involving all stakeholders and especially those who are evaluated, for example individuals, organizations or institutions (LEITE, 2005, 2009; FÉLIX; LEITE; PINHO, 2016; LEITE; PINHO, 2017b). 
Table 1 - Leiden Manifesto ten principles

1) Quantitative evaluation should support qualitative, expert assessment.

2) Measure performance against the research missions of the institution, group or researcher.

3) Protect excellence in locally relevant research.

4) Keep data collection and analytical processes open, transparent and simple.

5) Allow those evaluated to verify data and analysis.

6) Account for variation by field in publication and citation practices

7) Base assessment of individual researchers on a qualitative judgement of their portfolio.

8) Avoid misplaced concreteness and false precision.

9) Recognize the systemic effects of assessment and indicators.

10) Scrutinize indicators regularly and update them.

Source: the author based on Hicks et al. (2015).

\section{Planning the Research Evaluation Framework}

Implement a Research Evaluation System can be seen as a decision process chain. We must think, ask, debate and take decisions about our Research Evaluation Framework.

Once we know that there is no single way to organize the planning of the construction of an evaluation tool, we have chosen a guide that proposes to think about the key considerations that can be used by several stakeholders. The Association of American Medical Colleges (AAMC) asked RAND Europe to conduct a detailed synthesis of existing and previously proposed frameworks and indicators used to evaluate research. This review, made by Susan Guthrie, Watu Wamae, Stephanie Diepeveen, Steven Wooding and Jonathan Grant, also provide a guide to the key considerations that need to be taken into account when developing approaches to research evaluation, to be used as a resource by research funders, managers and policymakers (GUTHRIE et al., 2013). Those authors focus the analyze on six frameworks: 1) Research Excellence Framework (REF), from UK; 2) STAR METRIC, from US; 3) Excellence in Research for Australia (ERA); 4) Canadian Academy of Health Science (CAHS) Payback Framework; 5) National Institute of Health Research (NIHR) Dashboard; and 6) Productive Interactions, a framework developed across several countries in Europe.

Based on this report, we list the main questions that can drive the decision process to build a clear and adjust research Evaluation Framework Figure 2. 
Figure 2 - Framework building guide questions

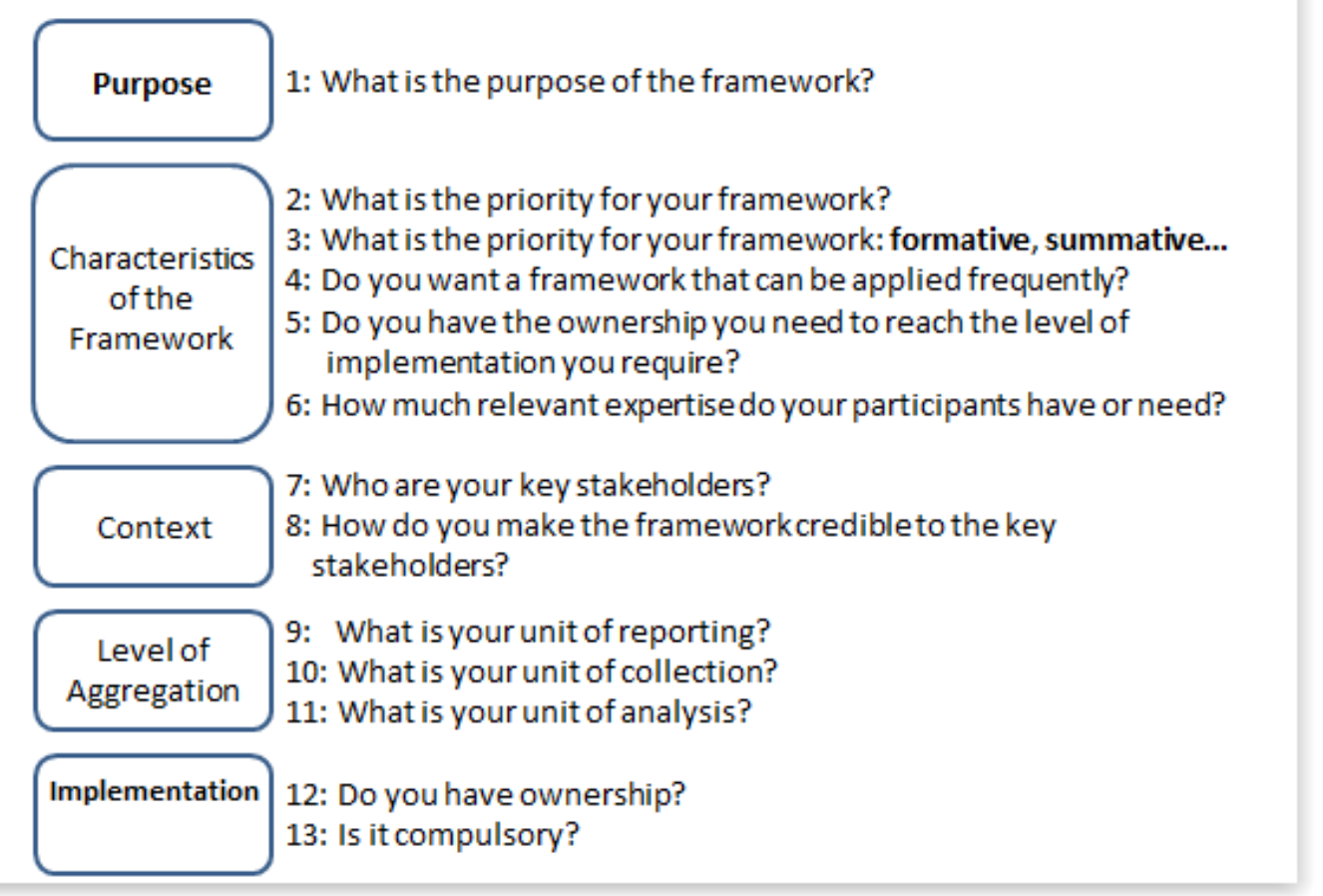

Source: building based on Guthrie et al. (2013).

The first step is defining the purpose; research evaluation can be conducted for one or more of some purposes: a) Advocacy, to demonstrate the benefits of supporting research, enhance understanding of research; b) Accountability, to show that money has been used efficiently and effectively, and hold researchers to account; c) Analysis, to understand how and why research is effective and how it can be better supported, feeding into research strategy and decision making by providing a stronger evidence base; d) Allocation, to determine where best to allocate funds in the future, making the best use possible of a limited funding pot.

The second step defines the Characteristics of the framework, and call for thinking about priority related to the types of indicators to be used, the scope, the users and the ownership of the Research Evaluation System. There is a need to choose if we want gathering longitudinal, quantitative data, or to have a low initial burden and draw largely on qualitative data, or even both. Also we need to define if the evaluation will be formative, flexible and comprehensive, or will be to produce data that allow comparison between institutions or programs. Issues about the frequency of evaluation apply and the ownership of the systems must be thinking. 
The third step is related to the Context of the Research Evaluation System. We need to define its key stakeholders in order to keep a friendly-use system, to all stakeholders.

The fourth step concern on select the tools that fall into one of two groups: a) formative tools that are flexible and able to deal with cross-disciplinary and multi-disciplinary assessment; b) summative tools that do not require judgement or interpretation, and are quantitative, scalable, transparent, comparable and suitable for high frequency, longitudinal use.

The fifth step for developing the framework is about the selection of aggregation for the collection, analysis and reporting of data. We must think about the interrelation between those decisions because if the unit of reporting focuses on the needs of the audience(s), the unit of data collection will depend on feasibility, burden and the selection of tools. The unit of analysis should be aligned with the questions we want put to the data.

To implement the System we must know who the ownership is, because the level of implementation depends of the ownership commitment. We also need to know the level of evaluation participation: compulsory, voluntary or participatory.

\section{Tools and Metrics}

In the same study of Susan Guthrie et al. (2013) the authors analyze the tools used in the six frameworks. They mapped on two axes and they found two groups (see Figure 3). Inside Group 1, we can find five tools: 1) Document Review; 2) Peer Review; 3) Site Visits; 4) Interviews and 5) Cases Studies. Inside Group 2 they insert four tools: 1) Bibliometrics; 2) Surveys; 3) Economic Analysis and 4) Data Mining. The Logic models are between the two groups. Choosing the right combination of tools that can meet the purpose of each evaluation is the key to build an effective system. 
Figure 3 - Mapping of tools against Group 1 and Group 2 characteristics

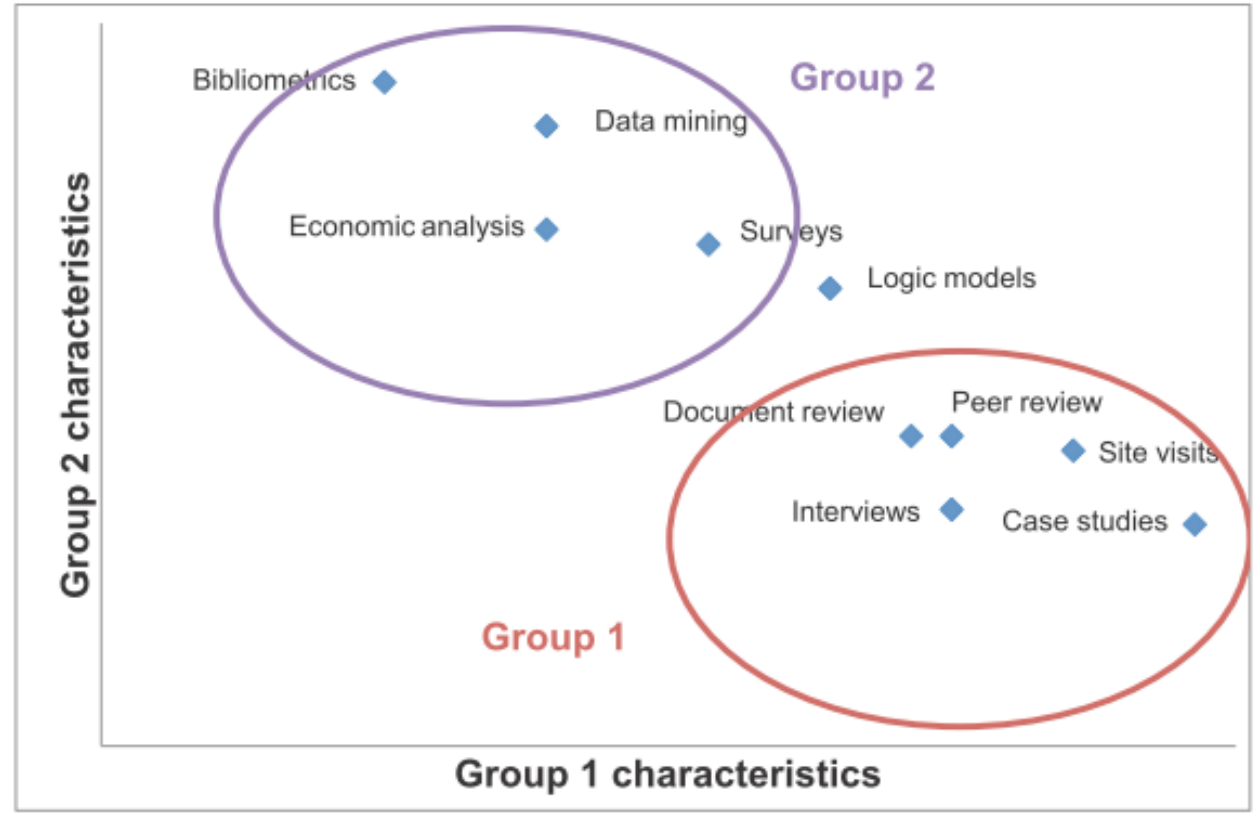

Source: Guthrie et al. (2013).

Tools and metrics reflect the evaluation criteria and explicit and implicit assumptions. If we only value the number of articles published in journals with "impact factor" as a measure of individual researcher performance we are taking a bias position inside the knowledge production space.

Another problem is related to the diversity across research fields on publications practices patterns. The use a national language sometimes is undervalued and even penalizing in terms of research evaluation; so if writing in English can facilitate the dissemination of knowledge at a global level writing in the national language should be valued and encouraged. The evaluation should reward the articles that had this double work.

Because the evaluation and the choice of indicators have impact, on the behaviors of people who are object of evaluation, we need to rethink about the use of the indicators. The design of evaluation systems both globally and nationally makes research funding dependent on the researcher's performance (BUTLER, 2003). These systems often reinforce publication in journals considered "mainstream" that exclude knowledge generated in other circuits (BEIGEL, 2014; SIDONE; HADDAD; MENA-CHALCO, 2016). Others newspaper indexing platforms have been growing in importance not only in national and international contexts. A pionee- 
ring example, both in full open access and in the range of publication languages, is the SciELO platform, which aggregates a joint effort of 14 countries for the valorization and visibility of their scientific production (Latin American countries, Portugal, Spain and South Africa (PACKER et al., 2014; VÉLEZ-CUARTAS; LUCIO-ARIAS; LEYDESDORFF, 2016).

Choosing the journal to publish is a decision that takes in account several criteria related to research evaluation (BUELA-CASAL; ZYCH, 2012). As researchers know that the newspaper's impact factor (JIF/Web of Science- Clarivate Analytics; SJR/Scopus-Elsevier) is used not only to characterize the newspaper as a whole but is also used improperly to assess individual researchers' performance they consider this criterion in their decision-making process (BALABAN, 2012; VAN NOORDEN, 2014; MUGNAINI; FUJINO; KOBASHI, 2017).

In the case of the evaluation of the research in Brazil, there is a complementary double of criteria regarding the quality of the newspaper; on the one hand, the bibliometric indicators proposed by the aforementioned databases are considered, and on the other, the Qualis classification of the journals proposes as a criterion the indexing of the newspaper to SciELO. (COORDENAÇÃO DE APERFEIÇOAMENTO DE PESSOAL DE NÍVEL SUPERIOR, 2012; TRZESNIAK, 2016; DE SOUZA et al., 2018).

Another widely used criterion is the number of citations of articles in a given time period. There are many factors for an article to be quoted or not. One factor can be the platforms where the journal is indexed. Rogerio Mugnaini, Ed Noyons and Packer, Abel verified that there is a relationship between the citation and the platform (2018). They identified about 400,000 original and review articles, published between 1998 and 2012, in journals indexed in the Web of Science (WoS) and/or SciELO; these articles were selected according to the criterion that at least one of the authors was linked to a Brazilian institution. The results showed the dynamic evolution of the distribution in these two platforms: at the beginning of the time period the journals indexed only in WoS published $73.1 \%$ of the national production and later, in 2012 this percentage decreased to 54.7\%; notice the growing increase of SciELO coverage of Brazilian knowledge production.

Looking by disciplinar perspective some results are relevant (see Figure 4). The "hard sciences", publish preferentially in indexed journals while the "soft sciences" publish in journals indexed to SciELO. 
Figure 4 - Distribution of cited and not cited articles in the corpus of SciELO and WoS journals

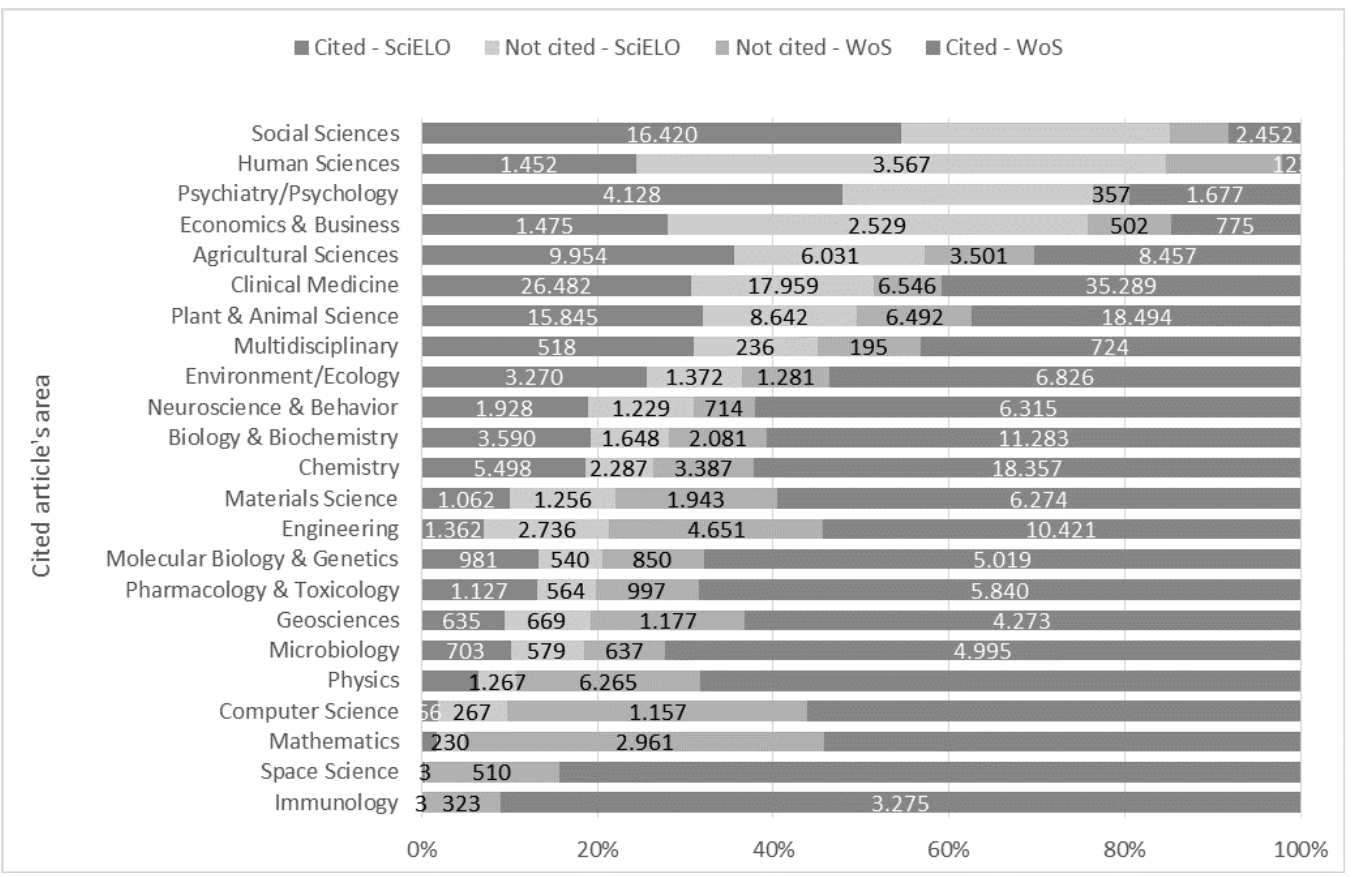

Source: Mugnaini, Noyons e Packer (2018).

Another variable that those authors study was the volume of articles cited in each platform (see Figure 5). The authors select only articles published in SciELO and look at its citations. The number of citations originating from the domestic flow (Brazilian articles in SciELO journals, in dark SciELO side) is significant in Social and Human Sciences, but also for Agrarian and Biological Sciences areas. The international impact of articles that can be given in citation inside WoS are also relevant in areas such as the called Exact Sciences, and areas related to Health Sciences and Biology). 
Figure 5 - Country afiliation

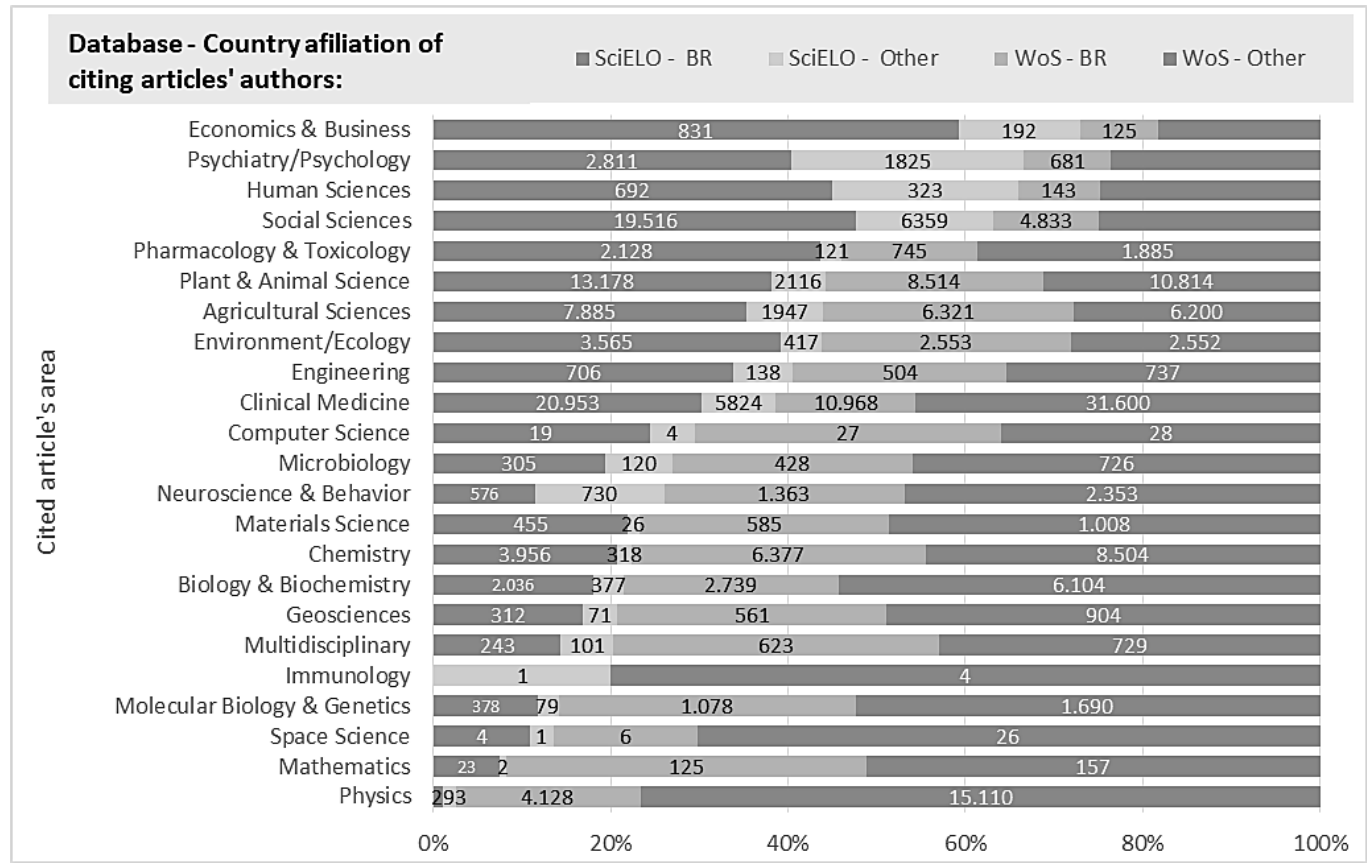

Source: Mugnaini, Noyons e Packer (2018).

\section{Research Networks}

The traditional evaluation of research encourages competition and even unethical behavior. Since collaboration is the main energy of the knowledge production process, it seems necessary to value this parameter in an evaluation that intends not only to balance the products produced but to go further and value collaborative work and to encourage ethical behavior and knowledge sharing for the production of knowledge as a common good with an impact on society.

In the book "Evaluating Collaboration Networks in Higher Education Research: Drivers of Excellence" the authors argue that in order to drive knowledge production, leaders must strive to improve their understanding of how research networks interact (LEITE; PINHO, 2017a). They noted that "among the key parameters in contemporary research, performance processes and outcomes must be included" (LEITE; PINHO, 2017a, p. 1). This social space of interaction, where research processes happen, can be manage with support of research evaluation that use "qualitative and quantitative data to uncover the interactive processes of doing collaborative research inside a network" (LEITE et al., 2018, p. 125). 


\section{Synthesis and future challenges}

The use of Research indicators serves different purposes in a spectrum scope from micro to macro level of analysis. Indicators are quantitative and qualitative observations that are supported by a conceptual/theoretical model.

The validity of the indicator depend of its context; we need understanding the characteristics of the various tools in order to choose the most effective ones to respond to our evaluation needs. To build a clear and useful framework is the result of a Chain Decision Process that begin with definition of the purpose of evaluation and finish with the identification of metrics set that we will use to build the Research Evaluation System (see Figure 6).

Figure 6 - Research Evaluation Chain Decision Process

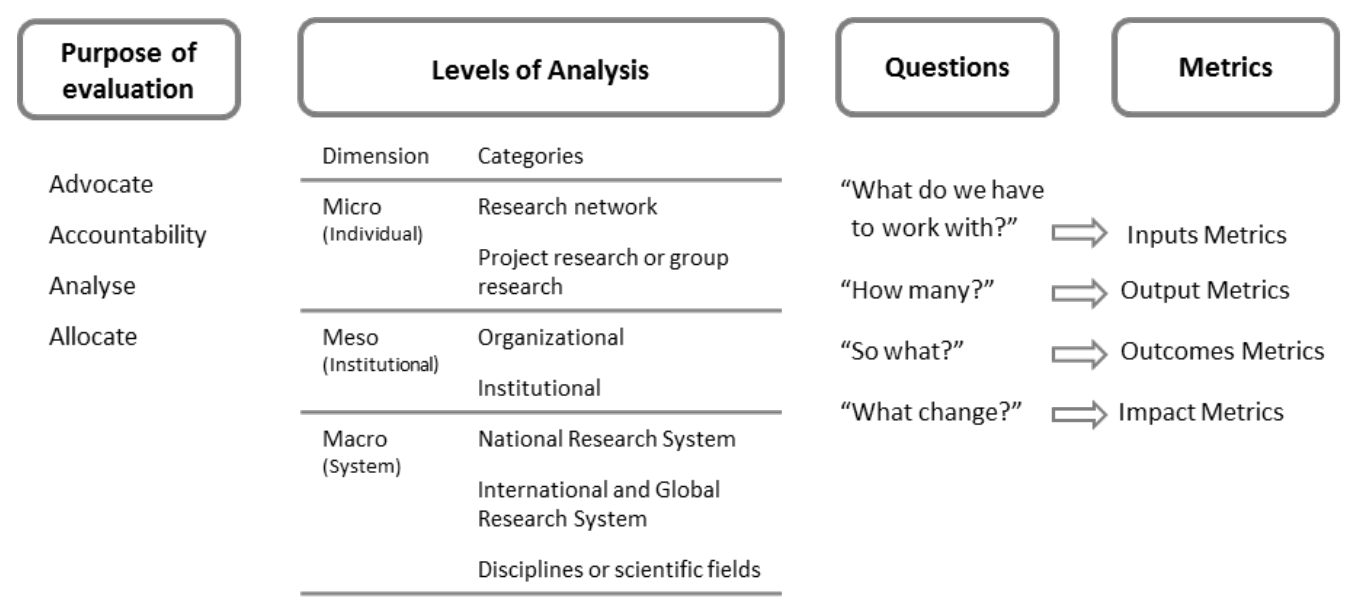

Source: the author.

The identification of Inputs metrics we take from the answer to the following question: What do we have to work with? This kind of metrics serves to evaluate the resources consumed in the implementation of an intervention. With the question, "How many?" we can think about measures the goods and services directly produced, the Output Metrics. But if we want measure the initial impact, that give the main reason we ask: So What? In this level we have the outcome metrics. Some evaluation aims to measure the long-term changes, using impact metrics. More and more Society and Governments expect researchers, academics and universities how they are relevant for positive changes on environmental, economic, technological and societal levels (MORGAN, 2014; PINHO; LEITE, 2017). This impact goes beyond from traditional scholarly impact giving by citation counts of the articles. 
Another emerged focus is the look to inside of the knowledge processes; when the purpose is to improve of production there is a need to evaluate and monitor the main processes that transform inputs in outputs (PINHO; REGO; CUNHA, 2012; PINHO; ROSA, 2017). New avenues are open to Research Evaluation support by new technological developments that provide access to global and local data. Those data and related systems need an increasing of integration focus on user-friendly usability for all stakeholders of Research Evaluation.

Finally, note that when we need to evaluate the Research Evaluation System, to improve it, we can (re)use this Chain Decision Process making adjustments.

\section{References}

BALABAN, A. T. Positive and negative aspects of citation indices and journal impact factors. Scientometrics, v. 92, n. 2, p. 241-247, Aug. 2012.

BEIGEL, F. Publishing from the periphery: structural heterogeneity and segmented circuits. The evaluation of scientific publications for tenure in Argentina's CONICET. Current Sociology, v. 62 , n. 5 , p. $743-765,2014$.

BERTOLIN, J.; LEITE, D. Quality evaluation of the Brazilian higher education system: relevance, diversity, equity and effectiveness. Quality in Higher Education, v. 14, n. 2, p. 121-133, 2008.

BOARDMAN, P. C.; CORLEY, E. A. University research centers and the composition of research collaborations. Research Policy, v. 37, n. 5, p. 900-913, 2008.

BOZEMAN, B.; CORLEY, E. Scientists' collaboration strategies: implications for scientific and technical human capital. Research Policy, v. 33, n. 4, p. 599-616, 2004.

BUELA-CASAL, G.; ZYCH, I. What do the scientists think about the impact factor? Scientometrics, v. 92, n. 2, p. 281-292, Aug. 2012.

BUTLER, L. Explaining Australia's increased share of ISI publications - the effects of a funding formula based on publication counts. Research Policy, v. 32, n. 1, p. 143-155, 2003.

COORDENAÇÃO DE APERFEIÇOAMENTO DE PESSOAL DE NÍVEL SUPERIOR. Comunicado $n^{o} 002$ / 2012 - área de educação. Brasília, DF: Ministério da Educação, 2012.

DE SOUZA, Â. R. et al. Qualis: a construção de um indicador para os periódicos na área da Educação. Práxis Educativa, v. 13, n. 1, p. 219-231, 2018.

FELIX, G. T.; GODOY BERTOLIN, J.; MOROSINI POLIDORI, M. Avaliação da educação superior: um comparativo dos instrumentos de regulação entre Brasil e Portugal. Avaliação: Revista da Avaliação da Educação Superior, v. 22, n. 1, p. 35-54, 2017.

FÉLIX, G. T.; LEITE, D.; PINHO, I. Duplo sentido da avaliação: a percepção dos estudantes sobre o desempenho docente. In: CIAIQ - IBERO-AMERICAN CONGRESS ON QUALITATIVE RESEARCH, 5., 2016, Porto. Anais... Porto: Ludomedia, 2016. p. 58-68. 
GLÄNZEL, W.; LETA, J.; THIJS, B. Science in Brazil. Part 1: a macro-level comparative study. Scientometrics, v. 67, n. 1, p. 67-86, 2006.

GUTHRIE, S. et al. Measuring research: a guide to research evaluation frameworks and tools. Santa Monica: Rand, 2013.

HANSEN, H. F. Choosing evaluation models: a discussion on evaluation design. Evaluation, v. 11 , n. 4 , p. $447-462$, Oct. 2005.

HICKS, D. et al. The Leiden Manifesto for research metrics. Nature, v. 520, n. 7548, p. 429-431, Apr. 2015.

LEITE, D. Reformas universitárias. Avaliação institucional participativa. Petrópolis: Vozes, 2005. 2009.

Avaliação participativa e qualidade. Os actores locais em foco. Porto Alegre: Sulina,

LEITE, D. et al. Research networks evaluation: indicators of interactive and formative dynamics. Comunicação \& Informação, v. 17, n. 2, p. 23-37, 2014.

LEITE, D.; PINHO, I. Evaluating Collaboration Networks in Higher Education Research: Drivers of Excellence. New York: Springer International Publishing - Palgrave Macmillan, 2017a.

LEITE, D.; PINHO, I. What is RNPE Evaluation? Does metrics mean the same? In: (Ed.). Evaluating Collaboration Networks in Higher Education Research: Drivers of Excellence. Cham: Springer International Publishing, 2017b. p. 79-102.

LEITE, D. et al. Methodological tracks to study research collaboration networks in higher education. In: HUISMAN, J.; TIGHT, M. (Ed.). Theory and Method in Higher Education Research. United Kingdom: Emerald, 2018. v. 4. p. 125-143.

LEYDESDORFF, L.; PERSSON, O. Mapping the geography of science: Distribution patterns and networks of relations among cities and institutes. Journal of the American Society for Information Science and Technology, v. 61, n. 8, p. 1622-1634, 2010.

MORGAN, B. Research impact: income for outcome. Nature, v. 511, 2014.

MUGNAINI, R.; FUJINO, A.; KOBASHI, N. Y. Bibliometria e cientometria no Brasil: infraestrutura para avaliação da pesquisa científica na Era do Big Data. São Paulo: ECA/USP, 2017.

MUGNAINI, R.; NOYONS, E.; PACKER, A. Fluxo de citações inter-nacional: fontes de informação para avaliação de impacto científico no Brasil. In: ENCONTRO BRASILEIRO DE BIBLIOMETRIA E CIENTOMETRIA, 6, 2018, Rio de Janeiro. Anais... Rio de Janeiro: EBBC, 2018. p. $473-481$.

PACKER, A. et al. SciELO - 15 Years of Open Access: an analytic study of Open Access and scholarly communication. Paris: UNESCO, 2014.

PACKER, A. L.; MENEGHINI, R. Articles with authors affiliated to Brazilian institutions published from 1994 to 2003 with 100 or more citations: I - The weight of international collaboration and the role of the networks. Anais da Academia Brasileira de Ciências, v. 4, n. 78, p. 841-853, 2006. 
PINHO, I.; LEITE, D. Avaliar o impacto da pesquisa. In: SEMINÁRIO INTERNACIONAL DE EDUCAÇÃO SUPERIOR, 10, 2017, Porto Alegre. Atas... Porto Alegre: Ufrgs, 2017. p. 1.

PINHO, I.; REGO, A.; CUNHA, M. P. Improving knowledge management processes: A hybrid positive approach. Journal of Knowledge Management, v. 16, n. 2, p. 215-242, 2012.

PINHO, I.; ROSA, M. J. Research Evaluation: the need to include processes and impact. In: CONGRESSO INTERNACIONAL DESAFIOS DA QUALIDADE EM INSTITUIÇOES DE ENSINO, 2, 2017, Coimbra. Anais... Coimbra: Escola de Enfermagem de Coimbra, 2017. p. 1-11.

QUINTELLA, R. et al. Mapa de Rede de Impactos como Tecnologia de Planejamento e Gestão Estratégica em Organizações de Grande Complexidade. Tecnologias de Administração e Contabilidade, v. 4, n. 1, p. 59-70, 2014.

QUINTELLA, R. H. et al. Network dynamics in scientific knowledge acquisition: an analysis in three public universities in the state of Bahia. Revista de Administração Pública, v. 43, n. 6, p. 1279-1314, 2009.

SIDONE, O. J. G.; HADDAD, E. A.; MENA-CHALCO, J. P. Scholarly publication and collaboration in Brazil: the role of geography. Journal of the Association for Information Science and Technology, v. 68, n. 1, p. 243-258, 2016.

SUN, S.; MANSON, S. M. Social Network Analysis of the Academic GIScience Community. Professional Geographer, v. 63, n. 1, p. 18-33, 2011.

TOIVANEN, H.; PONOMARIOV, B. African regional innovation systems: Bibliometric analysis of research collaboration patterns 2005-2009. Scientometrics, v. 88, n. 2, p. 471-493, 2011.

TRZESNIAK, P. Qualis in four quarters: history and suggestions for the Administration, Accounting and Tourism area. Revista Contabilidade \& Finanças, v. 27, p. 279-290, 2016.

VAN NOORDEN, R. The impact gap: South America by the numbers. Nature, v. 510, n. 7504, p. 202-203, 2014.

VÉLEZ-CUARTAS, G.; LUCIO-ARIAS, D.; LEYDESDORFF, L. Regional and global science: Publications from Latin America and the Caribbean in the SciELO Citation Index and the Web of Science. El Profesional de la Información, v. 25, n. 1, p. 35-46, 2016. 


\section{Annex 1}

Table 2 - Manifestos and declarations

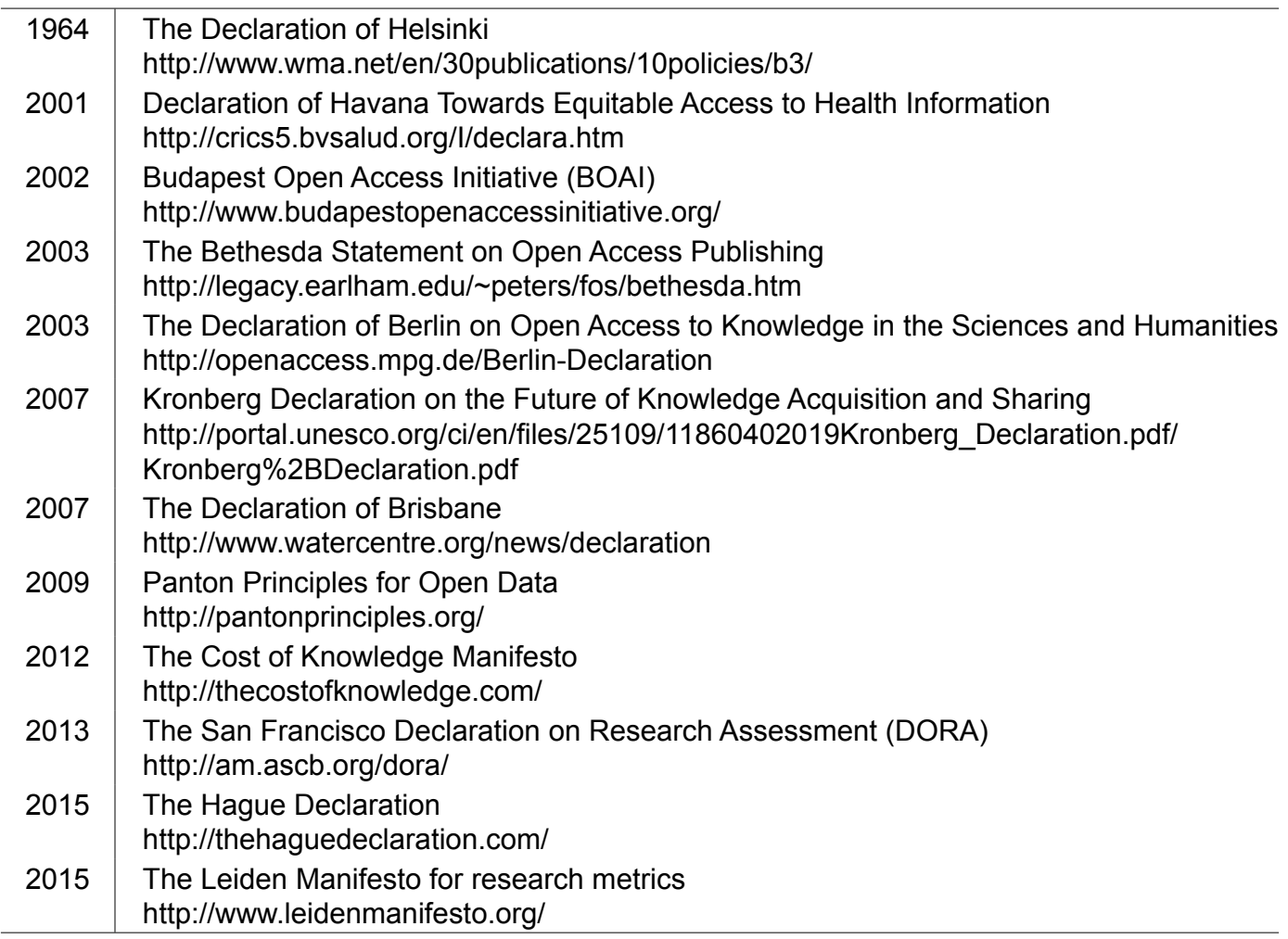

Source: the author based on Hicks et al. (2015). 